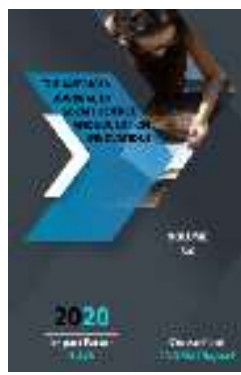

\title{
Basic Views On The Emergence And Development Of Agricultural Crop In Southern Uzbekistan
}

\author{
Tokhir Norkobilov Husanovich \\ Researcher, State Museum Of History Of Uzbekistan
}

Journal Website: http://usajournalshub.c om/index,php/tajssei

\section{ABSTRACT}

This article discusses the main views on the emergence and development of agricultural culture in Southern Uzbekistan. The question of the emergence of agriculture in southern Uzbekistan has been considered by researchers in connection with the history of the Bronze Age cultures of Northern Afghanistan and Southern Turkmenistan, as they have common developmental laws and historical roots. The study of the Namazgah cultures in southern Turkmenistan, the Dashtli cultures in northern Afghanistan, and the Sapalli cultures in southern Uzbekistan is one of the most important discoveries in Central Asian archeology and contains a wealth of scientific information on the history of the Bronze Age. During the Bronze Age, the areas where farmers lived were expanded by developing new lands. In these processes, migration is especially important - the migration of the population from one region to another and the emergence of agricultural culture in the Margiana and Bactria regions were associated with migration. According to the analyzed data, the main points of scientific views on the emergence and development of agricultural culture in Southern Uzbekistan are based on the theory of migration.

\section{KEYWORDS}

Southern Uzbekistan, Northern Afghanistan, Southern Turkmenistan, Bronze Age, Early Iron Age, agricultural culture, Namazgah, Dashtli, Sapalli, Margiana and Bactria, Sapallitepa, Jarqutan, Molali, Kuchuktepa, Yazdepa, Tillatepa, Tolliqon, Shurtoqay, migrations, Ox civilization, Turan civilization. 


\section{INTRODUCTION}

It is known that in different regions of the ancient East the first states and cities emerged on the basis of the development of productive farms and the separation of specialized crafts, due to socio-economic, cultural and political factors.

The issue of the emergence of agriculture in southern Uzbekistan has been considered by researchers in connection with the history of the Bronze Age cultures of Northern Afghanistan and Southern Turkmenistan, as they have common developmental laws and historical roots.

The study of the Namazgah cultures in southern Turkmenistan, the Dashtli cultures in northern Afghanistan, and the Sapalli cultures in southern Uzbekistan is one of the most important discoveries in Central Asian archeology and contains a wealth of scientific information on the history of the Bronze Age [Masson, 1959; Askarov, 1977; Sarianidi, 1977; Askarov, Shirinov, 1993]. In the publications of V.I. Sarianidi, the monuments and finds of the Bronze Age are called by a common name, the Bactrian-Margiana archeological complex [Sarianidi, 2001]. U.V. Rakhmanov proposed the introduction of the term Namazgah-Sapalli culture in science [Raxmanov, 1987. -P.17.]. According to A.S.Sagdullaev, within Bactria it is appropriate to call the culture of the Bronze Age Dashtli-Sapalli culture [Sagdullayev, 1989P.14.]. A.A. Askarov and T.Sh. Shirinovs called this culture the Sapalli-Dashtli archeological complex [Askarov, Shirinov, 1993, P.40-45].

After the material sources of the Bronze Age were widely covered in the scientific literature, foreign archaeologists began to apply the term civilization to these cultures. American researcher K.K. Lamberg-Karlovsky was the first to use the terms "Ox civilization", and the
Italian scientist M. Tozi - "Turan civilization" [Lamberg-Karlovsky, 1994, P.398-405; Tosi, 1989. - P.69-71].T.Sh. Shirinov uses the concept of "Turanian civilization" in his works [Shirinov, 2000. - P.27]. However, A.A. Askarov and T.Sh. Shirinov suggested linking the common Bronze Age cultures of southern Central Asia, Northeast Iran, and northern Afghanistan with the concept of the "The historical and cultural unity of Namazgah" [Askarov, Shirinov, 1993, P.42].

During the Bronze Age, the areas where farmers lived were expanded due to the development of new lands. In these processes, migration- the movement of the population from one area to another was especially important. The emergence of agricultural crop in the Margiana and Bactrian regions was associated with migration, i.e., the migration of the population to new lands.

Initially, A.A. Askarov speculated that during the Bronze Age, southern Uzbekistan was occupied by cultivators from northeastern Iran or southern Afghanistan and southern Turkmenistan [Askarov, 1973. -P.120-125]. The researcher compared the pottery and bronze weapons of the Sapalli culture with the findings of Mundigak in southern Afghanistan, Hissar and Shohtepa in northeastern Iran, and Namazgah in southern Turkmenistan. In his subsequent research, A.A. Askarov changed his mind a bit. In particular, the scientist noted that farmers in the southern part of Uzbekistan migrated from the agricultural oases of southern Turkmenistan. It was concluded that the similarities in the archeological artifacts of the Sapalli culture in the complexes of southern Afghanistan and northeastern Iran were influenced by their cultural ties [Askarov, 1973. -P.108-109]. 


\section{MATERIALS AND METHODS}

In the process of comparing the findings of pottery culture and monuments of Southern Turkmenistan (Namazgah, Oltintepa, Ulugtepa), especially in terms of shaping and production technology, ceramic vessels (vases, pots, jugs, bowls) and anthropological materials played an important role. A.A. Askarov noted the influence of the pottery of the Harappa culture on the bronze vessels of the Southern Uzbekistan (Surkhandarya oasis) and predicted the migration of representatives of this culture to the territories of northern Afghanistan [Askarov, 1977. -P.108-109].

In the 1970s, French archaeologists excavated the Tolliqan and Shurtuqay districts (northeast of the Panj River) in northeastern Afghanistan. They found and examined the remains of 26 settlements of the IV-II millennium [Gardin, Lyonnet, 1979. - P.99-154; Garden, 1982. -P.6-8]. During the Tolliqan period (3500-2500 BC) the ancient agricultural population of southern Afghanistan took an active part in the development of the eastern regions of Bactria [Lyonnet, 1977 - P.19-35]. During the Shurtuqay period (second half of the third millennium), representatives of the Harappa culture played an important role in migration processes [Frankfor, 1982. - P.30-32]. According to French scholars, such monuments as Shurtakay served as a trading post - a factor [Gardin, 1985. -P.3946].

We believe that natural resources, copper, tin, lead, gold, silver and precious stones have always been necessary for the development of metalworking and jewelry professions. This is evidenced by the location of Bronze Age monuments in the foothills of Bactria.

According to scientific views in the 70 s and early 80 s of the twentieth century, the emergence of agricultural crop in the regions of Margiana and Bactria was associated with different regions of the Ancient East. In particular, North India, Southern Afghanistan, Eastern Iran and Southern Turkmenistan are among them [Masson, 1974; Masson, 1982. P.10; Sarianidi, 1977.P.158; Garden, 1982.-P.7].

According to K.K. Lamberg-Karlovsky, the Oxus civilization, that is, the inhabitants of Margiana and Bactria expanded their territories at the expense of the lands of other tribes. This civilization is characterized by a highly developed defense system, with towers mounted on the walls of castles. The castles were built in the form of rectangles and circles. These large buildings included a castle where the chiefs lived, a temple that housed several architectural buildings, an inner palace, and other architectural complexes. They are fter occupation at the end of the III-millennium BC and at the beginning of the II-millennium $B C$, it may have been caused by conflicts and struggles for water and land resources. According to K.K.Lamberg-Karlovsky, the owners of the castles were also responsible for the organization of production, including farming, in the Bronze and Early Iron Ages. Researcher emphasizes the importance of animal husbandry in the emergence of Bactrian civilization, describing the rich tombs, the representation of camels, goats, deer in the fine arts, and intricate architectural structures as symbols of cultural ties between pastoralists and cultivators [Lamberg-Karlovsky, 1989. P.17-32].

On the emergence of Bronze Age culture in the regions of ancient Bactria, the French archaeologist P. Amiet writes: "In the mountainous and desert oases of outer Iran, under the influence of Mesopotamia and Susiana, "nomadic" or"nomadic-artisan" cultures were formed, and along with agricultural cultures lived livestock-artisan population. According to the researcher, fortresses such as Dashtli-3 served as a 
caravanserai and warehouse. These buildings also indicate the presence of aristocrats in the pastoral community [Amiet, 1989. - P.137-138].

M.Tosi writes that in Central Asia, animal husbandry and agriculture developed harmoniously, and international trade coordinated them. The researcher believes that the presence of rich objects in the graves of women found and examined in Sapallitepa is a characteristic of nomads [Tosi, 1989. - P.6971].

These ideas about the role of nomadic pastoralism in the development of cultures in Bactria and Margiana were considered and criticized by V.M. Masson and V.I. Sarianidi. Researchers were agreed that it is better to talk about shepherds living in the mountains and deserts of III-II millennia BC, and not nomadic pastoralists [Masson, 1988. - V.14; Amiet, 1988. - V.14].According to E.V.Antonova, V.M. Masson and V.I. Sarianidi mistakenly criticizedP. Amiet and M.Tozi. She writes that the word shepherd should be understood as neighbors of the peasants who have their own castles [Antonova, 1996. -P.197-240].

In determining the function of large buildings as castles, it is advisable to cite ethnographic data. According to B.V. Andrianov, 3/1 of the Turkic-speaking Qashqai population was sedentary and 3/2 was nomadic. They migrate in the Lur-Bakhtiar range and gather in the winter. Qashqai is a permanent wintering ground for nomadic pastoralists, consisting of rectangular, square-shaped buildings. The houses are built along the wall and the central part consists of an open area [Andrianov, 1985. $-P .150-151]$.

Excavations in the southern part of the Jarkutan fort have uncovered numerous bones, which have been found to belong to sheep, goats, and black cattle. The number of bones found also indicates that the population of the Sapalli culture developed animal husbandry. In our opinion, P. Amiet above mentioned conclusion is not sufficiently substantiated, that is the conclusion that the main part of the population of Bactria was cattle-breeders must be substantiated on the basis of various data. It is safe to say that the cattle were raised with the help of shepherds. Therefore, P. Amiet cannot agree with the idea that castle buildings such as the Bactrian Dashtli-3 served as warehouses for the cattle population.

In this regard, A.A. Askarov's conclusions should be quoted. Remains of grain (barley, wheat) were found in Sapallitepa. They are stored in jars. Numerous tools related to pottery cultivation, harvesting and processing of agricultural products have been found. According to the researcher, an average of 6070 hectares of land around Sapalli has been cultivated, and these and other data suggest that farming predominated in the lives of the people of Sapalli [Askarov, 1973. -P.130131.Askarov, 1977. -P.146-147]. In southern Uzbekistan (Surkhandarya oasis) during the Bronze Age mainly small cattle (sheep, goats) were grazed. This form of animal husbandry took over the mountains and developed in the steppe areas.

The question of the emergence and development of agriculture in the Bactrian regions in the late 1980 s was analyzed by A.S. Sagdullaev. According to the researcher, the formation and development of agricultural crop in Bactria dates back to the EneolithicBronze Age.Farmers have gradually developed the oases in the direction of the Amudarya in front of the Hindu Kush. It is proposed to divide the history of agricultural culture in Bactria into the following periods: 
1. Tolliqon period $(3500-2500 \quad B C)$. The emergence of early settlements in northeastern Afghanistan;

2. Shortoqay (second half of the III millennium BC). Development of lands along the Panj River;

3. Davlatabad (first quarter of the II millennium BC).

4. Dashtli-Sapalli (1700-1300 BC). Development of the lands of Northern Afghanistan and Southern Uzbekistan (Surkhandarya oasis);

5. Molali period (1300-1000 BC). The emergence of arable settlements in the oases at the foot of Boysun Mountain [Sagdullayev, 1989.- P.29].

According to A.S. Sagdullaev, the historicalcultural region (unity) of Bactria-Margiana was formed in the Bronze Age as a result of the spread of settled agricultural population with a common culture from the lower Murgab oasis to the Hindu Kush and Gissar foothills [Sagdullayev, 1987. - P.88]. This unity developed on a new basis in the Early Iron Age and is distinguished by its common features in terms of socio-economic, cultural and religious beliefs of the population.

According to the researcher, Sogd and Khorezm were also under the influence of the historical and cultural region of BactriaMargiana. Due to migration, the location of the population of Bactria-Margiana in these regions was estimated [Sagdullayev, 1989.Vol.XIX. - P.17].

It is possible to agree with A.S.Sagdullaev's opinion, because in different periods the historical and cultural regions united the tribes and ethnic groups located in the neighboring territories, which were in constant contact [Cheboksarov, Cheboksarova, 1982. -P.222].
According to the researcher, the main stages of development of the historical and cultural unity of Bactria-Margiana can be studied in connection with the spread of the East-Iranian ethnocultural unity, ie the gradual separation of the Bactrian, Sogdian and Khorezmian peoples [Sagdullayev, 1987. - P.88]. However, studying this topical issue based solely on archaeological data is a daunting task.

In the early 1990s, A.A. Askarov and T.Sh. Shirinovs considered the scientific views of the V.M. Masson, V.I. Sarianidi, V.A. Alekshin and B.A. Udemuradovs. As a result, researchers have linked the emergence of new agricultural hotspots in the Margiana and Bactria regions to migration, i.e., demographic, social causes due to the rapid population growth of the Bronze Age in various regions of the East[Askarov, Shirinov, 1993. - P.41-43].

The migration of the population from one region to another was typical of different periods. In the Bronze Age Margiana and Bactria, a continuous migration process is observed, in which the relationship between the beginning of migration (the old settlement area) and the acquired new territories is weakened, and the emergence of new tribes and ethnic groups in new agricultural centers can be predicted. According to the specialized scientific literature, the causes of permanent migration were varied. Among them are the most common types of migration due to demographic (population growth), socioeconomic reasons, ie the need to develop new areas (fertile lands), water and raw materials [Bruk, 1978. - P.51-52].

In recent years, this issue has been raised by O.M. Mavlonov made a special analysis and described the reasons for migration as follows [Mavlonov, 2008. -P.321]: 


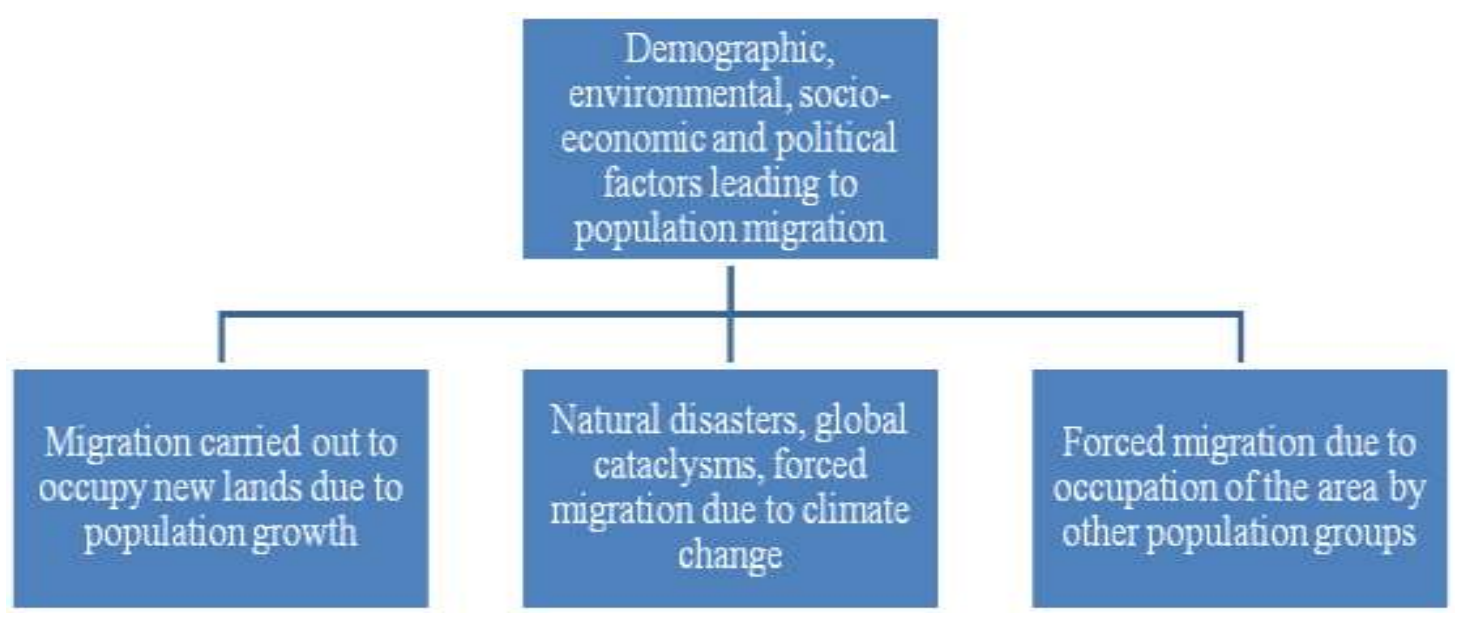

Based on the information reflected in the literature, it should be noted that in the regions of Margiana and Bactria, the agricultural crop and architectural traditions formed in the Ancient Eastern regions are widespread. V.I. Sarianidi noted the influence of the Mesopotamian building traditionsin the Dashtli-3 palace and temple, as well as the architectural plan of Sapallitepa [Sarianidi, 1977. - P.40]. According to K.K.LambergKarlovsky, in the II millennium BC, the Central Asian civilization (Margiana, Bactria) developed rapidly and was culturally equal to the Mesopotamian, Elamite and Indian civilizations [Lamberg-Karlovsky, 1990. -P.1218].

\section{RESULT AND DISCUSSION}

The French archaeologist A.P. Frankford in his monuments such as Shortoqay in Afghanistan and Mergar, Noshara in Pakistan, instead of the traditions of the Harappan culture, focused on the processes of the gradual spread of the material objects of Bactrian culture [Francfort, 1985. -P.95-104]. This process is also noted by K.K.Lamberg-Karlovsky[Lamberg-Karlovsky, 1990. -P.12].

Researchers have linked the migration of people from Mesopotamia to the Far East political migration, including migration to Iran and Central Asia. The conquest of fertile lands and the control of important trade routes led to wars between the Akkadian and Sumerian city-states [Yoffi, 1986. -P.20]. K.K. LambergKarlovsky provides information on the spread of Sumerian material culture in the northern and western regions of Iran[Lamberg Karlovski, 1986. - P.167-168]. By the end of the third millennium $B C$ - beginning of the second millennium $B C$, it can be assumed that as a result of the escalation of political conflicts and wars in Anterior Asia, civilians were forced to migrate to remote areas [Sagdullayev, 2010. P.63].

In ancient times, the type of migration arising out of necessity, which led to the development of new sources of raw material reserves, was also widespread. According to sources at the beginning of the second millennium $B C$, Assyrian trade caravans were sent to Afghanistan to buy tin products [Adams, 1986. - P.14]. During the Bronze Age, settlements in the oases of Northern Afghanistan and Southern Uzbekistan appeared on new lands to develop agriculture. The immigrants used the knowledge and practice gained in their home countries in the fields of construction methods, architecture, and handicrafts, and developed these industries in the new conditions in the developed areas.

According to the analysis of the above data, V.M. Masson, A.A. Askarov, V.I. Sarianidi, T.Sh. 
Shirinov one can agree with and other scholars that the agricultural crop in northern Afghanistan and southern Uzbekistan was formed as a result of population migration.

In our opinion, it is controversial to connect the cultures of Bactria and Margiana in the Bronze and Early Iron Ages with the concepts of "Turanian civilization" and "Outer Iran". The term "Turan" has been used in Persian literature, and the term "Iran" has been used since 1935 as the official name of the Persian state [Sagdullayev, 1996. -P.93-99]. From the point of view of historical-geographical and cultural features, it is expedient to use such terms in the scientific literature as "MargianaBactria archeological complex" [Sarianidi, 1990. - P.316], "Oks (Amudarya) civilization" [Boqiyev, Shaydullayev, Yo'ldosheva, 2015.P.176].

In the second half of the second millennium BC, cultural changes took place in the southern regions of Central Asia. Due to migration, the influx of livestock into the Dashtli-Sapalli cultures has spread. As a result, at the end of the 2nd millennium $B C$ - the beginning of the 1st millennium $B C$, the monuments Kuchuktepa and Kyzyltepa appeared in Northern Bactria and Tillatepa in Southern Bactria [Sarianidi, 1972. - P.19; Sagdullayev, 1978; Askarov, Albaum, 1979]. The material cultures of the Kuchuk I, Kyzyl I, and Tilla I periods are explained by exact similarities.

These cultures differ from the cultures of the indigenous population of the late Bronze Age, first and foremost, by their uniqueness in the field of pottery. Kuchuk I period pottery is mostly handmade and decorated with geometric (triangular, straight line) patterns with red paint on the outside [Lhuillier, 2013. P.103-146].

Scientists who have studied these changes in the field of material culture have observed various conclusions about the emergence of the cultures Yaz I, Kuchuk I, Tilla I. In this regard, conflicting views have been expressed in the science of Central Asian archeology. Emergence of Yaz I type in southern Turkmenistan E.Schmidt initially described this as "the result of an invasion of barbarians," in the 1950 s and 1960s, A.F. Ganyalin, A.A. Marushchenko, S.P. Tolstov and M.A. Itina's publications, the migration and settlement of cattle-breeding tribes living in the Eurasian region in Central Asia in the second millennium $B C$ was associated with the process of assimilation by local tribes [Shmidt, 1908, - Vol. I; Ganyalin, 1959. - P.86; Marushenko, 1959. P.70-72; Tolstov, Itina, 1960. - P.31-35].Many scholars argue that the roots of the Tilla I culture should be traced to the regions of Eastern Iran [Sarianidi, 1972. - P.19; Kuzmina, 1972. - P.137-138; Sarianidi, Koshelenko, 1985. P.203]. Commenting on the formation of the Kuchuk I culture in southern Uzbekistan, A.A.Askarov concluded that the formation of the Kuchuk I culture took place under the influence of the traditions of the Sapalli culture and as a result of the sedentary life of some cattle-breeding tribes. However, A.A. Askarov did not deny that the Kuchuktepa culture emerged as a result of the migration of part of the population of the Chust culture in Fergana to southern Uzbekistan (Surkhandarya oasis) [Askarov, Albaum, 1979. - P.72].

The issue of the spread of Andronovo culture in the southern regions was observed on the basis of material sources of Namazgah-SapalliDashtli cultures [Raxmanov, Shaydullayev, 1985. - P.58-63].

The issue of the influx of ethnic groups from the territories of Eastern Iran, put forward by V.I. Sarianidi, is denied by A.A.Askarov. According to A.A.Askarov and L.I.Albaum, the roots of the Kuchuktepa and Tillatepa cultures can be traced back to the Sarazm archeological 
complexes in ancient Sogd [Askarov, Albaum, 1979. - P.72-73].

A.A Askarov's article devoted to this issue suggests that the assimilation of the population of Sapalli culture by cattle-breeding tribes from the Mulali period formed the Kuchuk I culture, and that a part of the Chust culture moved directly to Bactria and formed the Kuchuktepa culture [Askarov,1979. -P.3437].

A.A. Askarov's opinion is based on the study of archeological sources. The researcher expressed this opinion in the 70s of the last century, when very few pottery fragments typical of steppe cultures were found in the Jarkutan monument. However, in later years, numerous specimens of material culture confirming the opinion expressed by A.A. Askarov were found and examined in Jarkutan. They show that cattle-breeding steppe inhabitants migrated to ancient farming areas [Raxmanov, Shaydullayev, 1985. - P.58-63; Avanesova, Tashpulatova, 1999. - P.27-36].

The abundance of pottery from the Jarkutan cultural strata and the Boston VI cemetery, the presence of bronze weapons, the presence of lightning rods, and the connections between the Sapalli culture and the cattle steppe tribes are multifaceted. The idea put forward by A.A.Askarov is fully confirmed in the example of Jarkutan material sources. From the time of Molali, the expansion of the Sapalli culture to the Kofirnihan, Vakhsh and Kyzylsu oases of southern Tajikistan, as well as the process of mixing with local livestock cultures, has been observed on the basis of material sources [Pyankova, 1989].

In the early 80 s and 9os of the twentieth century, European and American researchers also paid attention to this problem. They have their own views on the subject, and Yaz I culture marked by the middle of 2 nd millennium BC - 15th century. Researchers have noted that the Andronovo and Yaz I and Kuchuk I cultures are ethnically Indo-Aryan. The spread of the Indo-Aryans to India through Central Asia was linked to the crisis of the Harappan culture [Kohl, 1984; Hiebert, 1993. P.136-148; Hiebert, 1994. №42; Salvatori, 1993. - P.38-54].

As a result of recent research, the monuments of the Kuchuk I period appeared mainly in new areas, but no urban-type monuments were found in the territories of Southern Uzbekistan and Northern Afghanistan. At the same time, some traditions of construction of buildings belonging to the architecture of Sapalli-Dashtli cultures are inherited. Housing construction on a high foundation is inherited from the SapalliDashtli cultures [Shirinov, Shaydullayev, 1988. P.13-26].

According to the literature, in the late Bronze Age, due to the migration of northern steppe cattle-breeding tribes and agricultural groups from the south to Margiana and Bactria, moved to Lower Zarafshan and Khorezm regions as a result of the population of ancient agricultural oases increased [Sagdullayev, 1989. - P.55].

In recent years, different opinions have been expressed about the emergence of the Kuchuk I and Kyzyl I cultures [Shaydullayev, 2000. P.108-110]. In particular, the migration of East Turkestan tribes to the Bandikhan oasis of southern Uzbekistan is assumed [Sverchkov, Boroffka, 2009].

According to the analyzed data, the main aspects of scientific views on the emergence and development of agricultural culture in Southern Uzbekistan are based on the theory of migration. In particular, at the beginning of the XXI century, this problem was specifically addressed in the part of E.V. Rtveladze's monograph entitled "Migration of peoples as a 
factor in the development of civilizations" [Rtveladze, 2005. - P.32-49].

According to the researcher, the migration of ethnic groups, cultural and economic development, ethnic integration of tribes and peoples, the factors of assimilation has become a topic of debate in historiography. In ancient times, anthropological images and languages also changed as a result of the ethnocultural synthesis of indigenous peoples and foreign ethnoses. E.V. Rtveladze deals with the issue of Indo-European (Aryan) and Iranian tribes in the history of the Bronze and Early Iron Ages of Central Asia. This problem is connected with the history of Sapalli-Dashtli and Kuchuk I, Kyzyl I periods [Rtveladze, 2005. - P.33-36].

\section{CONCLUSION}

In conclusion, it should be noted that:

1. In the early 1970s, A.A. Askarov estimated that the emergence of agricultural culture in southern Uzbekistan was the result of the activities of farmers who migrated from northeastern Iran or southern Afghanistan and southern Turkmenistan;

2. In the late 70s, A.A. Askarov has changed his mind. Concluded that the migration of farmers to the territories of Southern Uzbekistan on the basis of the objects of ceramic material culture arose under the influence of cultural ties with Southern Afghanistan and Iran;

3. V.I. Sarianidi noted the influence of the Ikkidarya Range (Mesopotamia) and architectural traditions in the architectural plan of the Dashtli Palace and Temple in northern Afghanistan and Sapallitepa. Also, V.I. Sarianidi, K.K. Lamberg-Karlovski, R. Adams realized the scientific problem of the migration of the population of Old Asia to the far eastern regions. Terms such as Namazgoh-Sapalli, Dashtli-Sapalli, Bactria-Margiana archeological complex, "Turan civilization", "Ox civilization" were used in the naming of the culture of the Margiana-Bactrian Bronze Age, and this issue became controversial.

4. In the early 1990s, Summarizing the available data, A.A. Askarov and T.Sh. Shirinov linked the emergence of new agricultural centers in southern Uzbekistan with migration, ie demographic, social reasons due to population growth in the Bronze Age in various regions of the East;

5. In the literature published in the early 21st century, E.V. Rtveladze, A.S. Sagdullaev, O'.M. Mavlonov, Sh.B. Shaydullaevs revealed the demographic, environmental, socioeconomic and political causes of population migration, and the influence of external factors on the formation of agricultural culture in southern Uzbekistan. It was found that the ethnocultural intermingling of steppe cattle-breeding tribes and local agricultural population played an important role in the formation of the cultures of the Late Bronze Age (Puppy I, Red I). The idea of the migration of East Turkestan tribes to the territories of southern Uzbekistan has not been proven.

It should be noted that in southern Uzbekistan there are no traces of ancient agricultural crop compared to the Bronze Age Sapalli culture. The population who moved to Southern Uzbekistan (Surkhandarya oasis) applied the knowledge and experience gained in their homeland in the field of agriculture, 
architecture and handicrafts in the newly developed areas. The influence of the gradual migration of steppe cattle-breeding tribes to the regions of southern Uzbekistan in the Bronze Age was reflected in the material culture, burial rites and beliefs of the local population (research by U.V. Rakhmanov, N.A. Avanesova, Sh.B. Shaydullaev). At the end of the second millennium BC, Jarkutan, a large settlement, was in crisis. In this regard, it can be assumed that part of the arable population will be converted to the form of livestock farming, which is grazed on foothills.

According to new data, in the end of the second millennium $B C$. - the beginning of the first millennium BC (Kuchuk I, Kyzyl I period) houses appeared in Jarkutan in the form of basements and semi-basements [Mustafokulov, Bendezu-Sarmento, 2012. P.203-213; Bendezu-Sarmiyento, Lyuilye, 2015. P.26-45;Mustafakulov, Bendezu-Sarmyento, 2016. - P.267-274]. They reflect the methods of housing construction of the livestock population. However, the building styles, handicrafts and farming traditions typical of the Sapalli culture have not completely disappeared. During the Early Iron Age, the traditions of the Bronze Age culture developed on a new basis, and large areas of southern Uzbekistan were developed for agricultural purposes. Also, a new stage in the history of statehood and urban planning has begun.

\section{REFERENCES}

1. Adams R. Izucheniye bronzovogo veka Mesopotamii i sosednix regionov // DrevniyesivilizatsiiVostoka. - Tashkent: Fan, 1986. - S.14.

2. Amiet P. Elam and Baktria // Baktria. An Ancient Oasis Civilizations. - RomaVenezia, 1989. - P.137-138.

3. Amiet P. L'age des echanges interiraniens 3500-3700 avant J.-C.
Paris,1986 // Informatsionniy byulleten' MAIKSA, M.: 1988. - Vip.14-S. 99-100.

4. Andrianov B.V Neosedloye naseleniye mira (Istoriko-etnograficheskoye issledovaniye). - M.1985. - S. 150-151.

5. Antonova E.V. Kontakti Mesopotamii s vostochnimi zemlyami v IV-III tis.do n.e /l Aziya - dialog sivilizatsiy. - S. Peterburg, 1996. - S. 197-240.

6. Askarov A.A. Drevnezemledel'cheskaya kul'tura epoxa bronzi yuga Uzbekistana. Tashkent: Fan, 1977. - S.108-109.

7. Askarov A.A. K voprosu o proisxojdenii kul'turi plemen s raspisnoy keramikoy epoxi pozdney bronzi i rannego jeleza // Etnografiya i arxeologiya Sredney Azii. - M.: Nauka,1979. - S.34-37.

8. Askarov A.A. Sapallitepa. - Tashkent: Fan, 1973. - S.120-125.

9. Askarov A.A., Albaum L.I. Poseleniye Kuchuktepa. - Tashkent: Fan, 1979;

10. Askarov A.A., Shirinov T.Sh. Rannyaya gorodskaya kul'tura epoxi bronzi yuga Sredney Azii. - Samarkand, 1993;

11. Avanesova N.A., Tashpulatova N. Simvolika ognya $v$ pogrebal'noy praktike Sapallinskoy kul'turi (po materialam issledovaniya mogil'nika Bustan VI) // IMKU. - Samarkand, 1999. - Vip. 30. - S.27- 36.

12. Bendezu-Sarmiyento X., Lyuil'ye J., Mustafakulov S., Raximov K. Pogrebal'naya praktika naseleniya rannego jeleznogo veka: noviye naxodki iz Djarkutana $v$ Severnoy Baktrii // Vestnik MITSAI, vipusk 22, 2015. S. 26-45;

13. Boqiyev A., Shaydullayev A., Yo'ldosheva Z. Oks sivilizatsiyasi. Toshkent: Yangi nashr, 2015. - 176 b.

14. Cheboksarov N.N., Cheboksarova I.A. Narodi, rasi, kul'turi. - M.: Nauka, 1982. $-\mathrm{S} .222$. 
15. Francfort N.P. Tradition harapeenne et innovation bactrienne a' Shortughai // Archeologique de la Bactrianne Ansienne. - Paris, 1985. - P.95-104.

16. Frankfor N.P. Xarappskaya traditsiya i baktriyskaya innovatsiya $v$ Shortugaye // Drevneyshiye kul'turi Baktrii: Tez. dokl. simpoziuma. - Dushanbe: Donish, 1982. - S.30-32.

17. Ganyalin A.F. K stratigrafii Namazgatepe // TIIAE AN TSSR. - Ashxabad, 1959. - Vip.II. 1956. - S.86;

18. Garden J.K. Ob arxeologicheskoy geografii Sredney Azii // Drevneyshiye kul'turi Baktrii: Tez. dokl. simpoziuma. - Dushanbe: Donish, 1982. - S.6-8.

19. Gardin J.C. Pour une geographie archeologique de la Bactriane: Actes du collogue franco - sovietique. - Paris, 1985. - P.39-46.

20. Gardin J.C., Lyonnet B. La prospection archeologique de la Bactriane Orientale (1974-1978): premiers resultats // Mesopotamia. - 1978-1979. - Vol. XIII-XIV. - P.99-154;

21. Hiebert F.T. Chronology of Margiana and Radiocarbon Dates // Information Bulleten of IASCCA. - Moskov, 1993, Issue 19. - P.136-148;

22. Hiebert F.T. Origins of the Bronze Age Oasis Civilization in Central Asia // American School of Prehistorik Research Bulleten. - Cambridge, 1994, - №42;

23. Kohl Ph.L. Central Asia. Paleolithic Beginnings to Early Iron Age. - Paris, 1984.

24. Kuzmina E.E. Kul'tura Svata i yee svyazi s Severnoy Baktriyey // KSIA. - M., 1972. - Vip.32. - S.137-138;

25. Lamberg - Karlovski K.K. Konturi drevneyshey istorii Iranskogoplato // Drevniyes ivilizatsii Vostoka. Tashkent: Fan, 1986. - S.167-168.
Lamberg - Karlovski K.K. Modeli vzaimodeystviya ot Mesopotamii do dolinilnda // VDI. - M., 1990. - №1. S.12-18.

26. Lamberg-Karlovsky C. The Bronze Age of Baktria // Baktria. An Ancient Oasis Civilizations. - Roma-Venezia, 1989. R. 17-32.

27. Lamberg-Karlovsky C.C. The Bronze Age khanates of Central Asia // Antiquity. - Rom, 1994,Vol. 68 - R. 398405.

28. LhuillierJ. Les cultures à céramique modelé epeinteen Asiecentrale: unaperçu del' assembla gecéramique de la de uxièmemoitié du II emillénaire av. J.-C.Iranica Antiqua 48, 2013. R. 103146.

29. Lyonnet B. Decouverte desites L'age Bronze dansle N. E. de L'Afganistan: leurs rapports avec la civilization de L'Indus // Estratto da Annali dell' Istituto oriental di Napoli. - Napoli, 1977 - Vol.37 - P.19-35.

30. Marushenko A.A. Yelken-depe // TIIAE AN TSSR. - Ashxabad, 1959. - Vip.V. S.70-72;

31. Masson V.M. Afganistan $v$ drevnosti // IstoriyaAfganistana. - M.: Misl', 1982. S.10;

32. Masson V.M. Drevnezemledel'cheskaya kul'tura Margiani // MIA, - L., 1959, №73;

33. Masson V.M. Problema drevnego goroda i arxeologicheskiye pamyatniki Severnoy Baktrii // DrevnyayaBaktriya. - L.: Nauka, 1974. - S.7;

34. Masson V.M. Protobaktriyskiy blok drevnevostochnix sivilizatsiy (K vixodu knigu: Amiet P. L'age des echanges inter-iraniens 3500-3700 avant J.-C. Paris, 1986) // Informatsionniy byulleten' MAIKSA, M.: 1988. Vip.14; 
35. Mavlonov O'.M. Markaziy Osiyoning qadimgi yo'llari: shakllanishi va rivojlanishi bosqichlari. - Toshkent: Akademiya, 2008. - B.321.

36. Mustafakulov S., Bendezu-Sarm'yento X., Raxmanov U., Lyuil'ye J., Raximov K., Dyupon A. Arxeologicheskiye issledovaniya na Djarkutane v 2013 g. // Arxeologicheskoyeissledovaniya $\mathrm{V}$ Uzbekistane 2013-2014 goda. Vipusk 10. Samarkand, 2016. S. 267-274.

37. Mustafokulov S., Bendezu-Sarmento X., Raxmonov U., Xasanov M., Lyuil'ye J., Lyuno E. Poleviye raboti uzbekskofransuzskoy (MAFOUZ) ekspeditsii na Djarkutane v 2009-2011 gg. /I Arxeologicheskiye issledovaniya $\mathrm{v}$ Uzbekistane 2010-2011 godi. Vipusk 8. Samarkand, 2012. S. 203-213;

38. Problemyetnicheskoygeografiiikartogr afii / Otv. red. S.I.Bruk. - M.: Nauka, 1978. - S.51-52.

39. Pyankova L.T. Drevniy eskotovodi Yujnogo Tadjikistana. - Dushanbe: Donish, 1989.

40. Raxmanov U.V. Keramicheskoye proizvodstvo epoxi bronzi Yujnogo Uzbekistana: Avtoref. diss... kand. istor. nauk. - Samarkand: Institut arxeologii, 1987. - S.17.

41. Raxmanov U.V., Shaydullayev Sh.B. O vliyani i kul'tur stepnoy bronzi na keramicheskiye kompleksi Sapallinskoy kul'turi // ONU. - Tashkent, 1985. - №11. - S.58-63.

42. Rtveladze E.V. Sivilizatsii, gosudarstva, kulturi sentralnoy Azii. - Tashkent: B.i., 2005. - S.32- 49.

43. Sagdullayev A.S. Etnokul'turniye protsessi v SredneyAzii v drevnosti // Qadimgi davlatchilik va urbanizatsiya (tarixiy lavhalar). - Toshkent: Mumtozso'z, 2010. - S.63.
44. Sagdullayev A.S. $\mathrm{K}$ izucheniy uposeleniya Mullali // Krayevedeniye Surxandar'i. - Tashkent: Uzbekistan, 1989 - S.14.

45. Sagdullayev A.S. Kul'tura Severnoy Baktrii $v$ epoxu pozdney bronzi $i$ rannego jeleza (Po materialam pamyatnikov rayona ShurchiBaysuna): Atoref. diss... kand. istor. nauk. - L.: Leningradskoye otdeleniye Instituta arxeologii AN SSSR, 1978.

46. Sagdullayev A.S.MargianaiBaktriya. Istoricheskiye traditsii i kul'turniye svyazi v do antichnuyu epoxu // Drevneymerv. - Tr. YUTAKE. Ashxabad: Ilim, 1989. - T.XIX. - S.17.

47. Sagdullayev A.S.Nekotoriye aspekti problem i proisxojdeniya sredneaziatskix kompleksovtipa Yaz I // SA. - M., 1989. - S.55.

48. Sagdullayev A.S. Osnovniye cherti i genezis kul'turi do antichnoy Baktrii // Antichniye iranne srednevekoviye drevnosti Yujnogo Uzbekistana. Tashkent: Fan, 1989. - S.29.

49. Sagdullayev A.S. Qadimgi O'zbekiston ilk yozma manbalarda. - Toshkent: O'qituvchi, 1996. - B.93-99.

50. Sagdullayev A.S.Usadbydrevney Baktrii. - Tashkent: Fan, 1987. - S.88.

51. Salvatori S. Protohistoric Margiana: on a Resent Contribution. (Reviev of: «IASCCA. Information Bulleten», 19 Moskov, 1993 // Revista di Arheologia. Venice, 1995. - Anno XIX. - P.38-54.

52. Sarianidi V.I, Koshelenko G.A. SrednyayaAziya $v$ ranne mjeleznom veke // Drevneyshiyego sudarstva Kavkazai Sredney Azii. Arxeologiya SSSR. - M.: Nauka, 1985. - S.203.

53. Sarianidi V.I. Drevniye zemledel'si Afganistana. - M: Nauka. - 1977.

54. Sarianidi V.I. Drevnosti strain Margush. - Ashxabad: Ilim, 1990. - 316 s. 
55. Sarianidi V.I. Nekropol' Gonura I iranskoye yazichestvo. - M: Nauka, 2001.

56. Sarianidi V.I. Raskopki Tillyatepe Severnom Afganistane. - M.: Nauka, 1972. - S.19;

57. Shaydullayev Sh.B. Severnaya Baktriya v epoxu rannego jeleznogo veka. Tashkent: Xalq Merosi, 2000. - S.108110.

58. Shirinov T.SH. Turanskaya sivilizatsiya Baktrii i Margianivo II tis. don.e. // Kul'turnoye naslediye Turkmenistana:Tez. dokl. - Ashxabad. - SPb, 2000. - S.27.

59. Shirinov T.Sh., Shaydullayev Sh.B. K voprosu $O \quad$ xronologicheskoy periodizatsii Kuchuktepa // IMKU. Tashkent, 1988. - Vip. 22. - S.13-26.

60. Shmidt E. Archaeological Excavation Anau and old Merv // Pampelly. Explorations in Turkestan.

Washington, 1908, - Vol. I;

61. Sverchkov L.M., Boroffka N. O nekotorix problemax arxeologicheskogo issledovaniya kul'tur raspisnoy keramiki epoxy pozdney bronzi - rannego jeleza Tashkentskogo oazisa // Stolitse Uzbekistana Tashkentu 2200 let. Materiali mejdunarodnoy nauchnoy konferensii. Tashkent: Fan, 2009.

62. Tolstov S.P., Itina M.A. Problema suyarganskoy kul'turi // SA. - M., 1960. - №1, - S.31-35.

63. Tosi $M$. The Origins of Early Bactrian Civilization // Baktria. An Ancient Oasis Civilizations. - Roma - Venezia, 1989. P. 69-71.

64. Yoffi N.Y. Sferi vzaimodeystviya $v$ Mesopotamii // Drevniye sivilizatsii Vostoka. - Tashkent: Fan, 1986. - S.120. 